\section{エンドトキシンによるラット肝内 isoーメタロチオネインの誘導}

\section{長井昭宏・高橋 徹・多賀直行・日高秀邦・ 原田圭子・板野義太郎・平川方久*}

\section{rapid communication}

Induction of hepattic metallothioneins determined at isoprotein level in endotoxin-treated rats

In order to clarify the induction of hepatic metallothioneins (MTs) as an acute phase reactant by endotoxin (lipopolysaccharide; LPS) shock further, induction of MT-I and MT-II by LPS was determined by high-performance liquid chromatography coupled with atomic absorption spectrophotometry. Rats were injected with LPS $(5 \mathrm{mg} / \mathrm{kg})$ and the hepatic concentrations of $\mathrm{Zn}-\mathrm{MT}-\mathrm{I}$ and $\mathrm{Zn}-\mathrm{MT}-\mathrm{II}$ were determined at $0,3,6,12,18$, and 24 hours after the injection. Time-course experiments showed that MT-II predominantly accumulated in comparison to MT-I. The MT-II increased rapidly at 6 hours after the injection, reached the maximum at 18 hours and then decreased gradually. All of these values were significantly different from those values of MT-I. These results suggest that MT-II may play some role in acute phase response during endotoxin shock.

Akihiro Nagai • Toru Takahashi • Naoyuki Taga • Hidekuni Hidaka - Keiko Harada . Yoshitaro Itano - Masahisa Hirakawa* key words: endotoxin, iso-metallothioneins, zinc

metallothionein(MT)は, 分子量約 6,100 の蛋白 質で, 約61個のアミノ酸残基のうち20個がシステ インであり，芳香族アミノ酸やヒスチジンを含ま ないという特異なアミノ酸組成を有している11. また，重金属に高い親和性を示し，亜鉛チオネイ ン(Zn-thionein) としては，通常 1 分子中に 7 個の 亜鉛原子を含んでいる1． また，ラットでは少な くとも MT-I , MT-II の 2 種の isoforms(iso$\mathrm{MTs}$ )が存在する ${ }^{1)}$. 重金属やグルココルチコイド は, MT の primary inducer である ${ }^{1)}$.一方, in vivo では，エンドトキシン(lipopolysaccharide, LPS)投与, 熱傷, 放射線照射などのストレスによ っても肝内に MT が合成される1,2).

MT の生理学的役割としては, 従来より, 重金

* Department of Anesthesiology and Resuscitology, Okayama University Medical School 岡山大学医学

$\therefore$. 部麻酔・蘇生学教室
属の解毒, 必須微量元素の代謝が報告されてきた が1)，1985年，free radical scavenger 作用を有す ることが報告されている゙3.

筆者らは，MT が生体防御に果たす役割に注目 し，LPS 投与時の急性期反応としての肝臓におけ る iso-MTs の誘導を, 高速液体クロマトグラフ ィー(HPLC) と原子吸光分光光度計 (AAS)を組み 合わせた Klaassen $ら^{4)}$ の方法を用いて測定し検討 したので報告する。

\section{方 法}

Wistar 系雄性 ラット(7 週齢)飞 LPS(E. coli 0127 : B8, Difco Lab.) $5 \mathrm{mg} / \mathrm{kg}$ 体重を腹腔内投 与した。投与 $0 ， 3 ， 6 ， 12 ， 18 ， 24$ 時間後に断頭 し, 肝臓を摘出, 窒素ガスで充媜した $1 \mathrm{mM}$ dithiothreitol を含む $10 \mathrm{mM}$ Tris $\mathrm{HCl} \mathrm{pH} 7.4$ を, 2 倍容加兄て破挽し, $12,000 \times \mathrm{g}$ にて 30 分間遠心 分離し，上清をさらに， $100,000 \times \mathrm{g}$ にて 60 分間 遠心分離し，細胞質可溶性画分を得た。これを $100^{\circ} \mathrm{C} 1$ 分間熱処理し， $15,000 \times \mathrm{g}, 3$ 分間遠心 分離したのち上清を濾過して試料とした。試料 $200 \mu 1$ を anion-exchange column(DEAE-5PW, $75 \times 7.5 \mathrm{~mm}$; 東ソー)を組み込んだ HPLC 装置に 添加し, 移動相 A : $10 \mathrm{mM}$ Tris $\mathrm{HCl} \mathrm{pH} 7.4$, B : $200 \mathrm{mM}$ Tris $\mathrm{HCl} \mathrm{pH} 7.4$, 直線勾配 $0 \sim 100$ $\% \mathrm{~B} / 12 \mathrm{~min}$, 流速 $1 \mathrm{ml} / \mathrm{min}$ で溶出した. 溶出液 の亜鉛濃度を HPLC に直接連結した AAS にて 測定し, MT ピークの亜鉛量を肝湿重量当りに換 算し, Zn-thionein isoroforms を定量した。

これとは別に，ラットに亜鉛を投与し，肝細胞 質可溶性画分を Sephadex G-75, DEAE Sephadex A-25を用いて，MT-I および MT-II を精製し， 標準品として用いた。

\section{結 果}

LPS 投与ラット肝の, MT- I , MT-II のピー クの保持時間は, 6.3 分, 9.8分であり, 標準品の iso-MTs の保持時間と一致していた（図 1). MTI は, 経時的に増加傾向を示し，12〜18時間後に 低いプラトーに達した。，MT-II は，3 時間後よ り増加傾向がみられ，6時間から24時間まで有意 に増加した。18時間では 0 時間の約25倍に達し, 24時間でやや減少した。 全経過を通じて，MTII が MT-I にくらべ常に量的に優位な iso-MT 
であった(図 2 ).

\section{考 察}

人や動物における血清亜鉛は，正常時きわめて 一定に保たれているが，感染症では急激に減少す る. Sobocinski ら ${ }^{2)}$ は, ラット腹腔に細菌を投与 すると，血清亜鉛の低下，肝内亜鉛の增加がみら れ，このとき肝内に Zn-thionein が誘導されるこ とを報告した、筆者らもラットにLPSを投与し， 同様の結果を得ている5).

今回, LPS による MT 誘導をさらに明らかに するために，iso-MTs の誘導について経時的な検 討を行った. LPS を投与したラットの MT-IIは, MT-I に対して経過中のあらゆる時間において 圧倒的に優位な iso-MT であった.

Klaassen $5^{6)}$ は，ラットに亜鉛を投与し，本法 を用いて MT-isoform の誘導について検討した. その結果，亜鉛投与の場合は LPS 投与ほどでは ないが，MT-II が比較的優位に誘導されること を報告し， MT-II の半減期が MT-I よりなが いことをその主な原因としている。したがって， MT-I は MT-II よりも速く turn over する蛋 白であり，MT-II は MT-I にくらべてょり安 定な isoform であると思われる。

一方, 今回の実験で筆者らは, Zn-thionein を 定量した. Winge ら゙は, MT-II が MT-I に くらべて亜鉛により親和性が高いことを報告して いる.

また，Klaassen ら ${ }^{8)}$ はデキサメサゾン投与ラッ トの肝内 MT-isoform 誘導についても検討し, 全 経過を通じて MT-II が MT-I に対して圧倒的 に優位な iso-MT であることを報告している。さ らに, 肝切除後には, 肝内に MT-II が優位に誘 導されることが報告されている9.

LPS 投与のようなストレス下では, 副腎皮質よ りグルココルチコイドの分泌が増加するので, 血 中に増加したグルココルチコイドが MT 誘導に 係わっていると考觉られる。ささら LPS 投与で は，LPS 刺激マクロファージなどから遊離したイ ンターロイキンなどのサイトカインも MT 誘導 に係わっていると考觉られる10).

今回，LPS 投与によって MT-II が MT-I に くらべて圧倒的に優位に誘導された理由は明らか ではない。しかし，MT-II がより安定な isoform a) purified rat liver iso-MTs

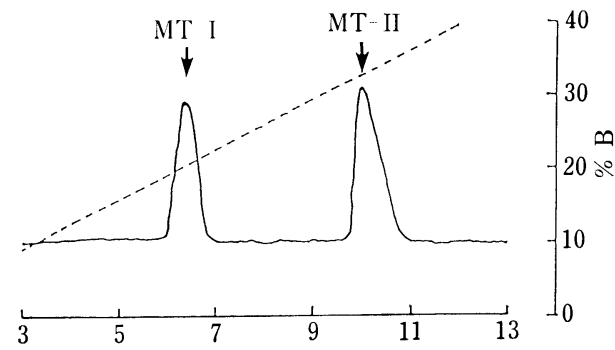

(b) LPS treated heat denatured rat liver cytosol

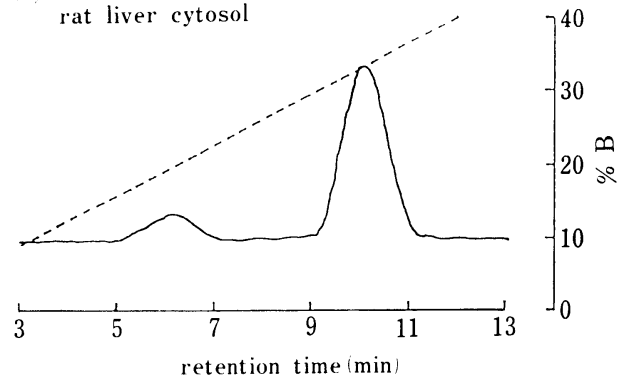

Zn $0.1 \mathrm{ppm}$

図 1 Chromatographic properties of MTs as determined by HPLC-AAS

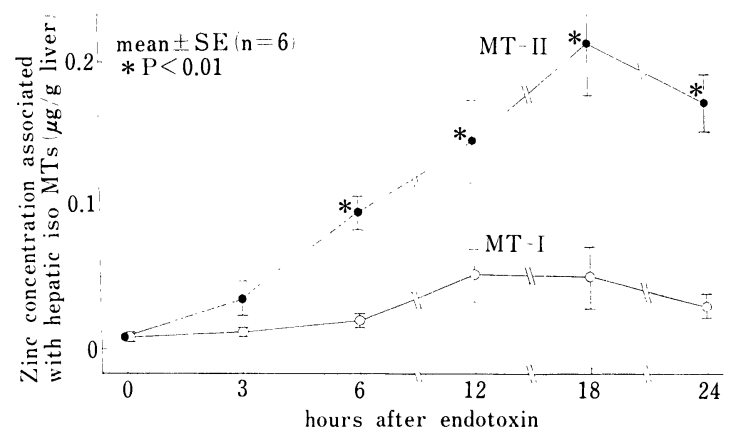

図 2 Time course for induction of hepatic isoMTs following LPS administration

であること，MTーII が亜鉛に親和性が高いこと 以外に, LPS 投与という侵襲によって血中に増加 するグルココルチコイドやサイトカインのような 物質が, MT-II の誘導, 安定化に寄与している 可能性も考光られる。一方, MT-I と MT-II の作用の差異については，いまだ不明である。し かし，今回の結果より LPS 投与による急性期反 応に和いては，MT-II がなんらかの役割を果た 
していると思われる。

本稿の要旨は, 第11回日本炎症学会(於東京)に おいて報告した。

\section{文 献}

1) Hamer, D.H.: Metallothionein. Ann. Rev. Biochem. 55: 913-951, 1986.

2) Sobocinski, P.Z., Canterbury, W.J., Mapes, C.A., Dinterman, R.E.: Involvement of hepatic metallothionein in hypozincemia associated with bacterial infection. Am. J. Physiol. 1234: E339 -E406, 1978.

3) Thornalley, P.J., Vasak, M.: Possible role for metallothionein in protection against radiationinduced oxidative stress; Kinetic and mechanism of its reaction with superoxide and hydroxyl radicals. Biochim. Biophys. Acta 827: 36-44, 1985.

4) Lehman, L.D., Klaassen, C.D.: Separation and quantitation of metallothionein by high-performance liquid chromatography coupled with atomic absorption spectrophtometry. Anal. Biochem. 153: 305-314, 1986.

5) Abe, S., Matsumi, M., Tsukioki, M., Mizukawa,
S., Takahashi, T., Iijima, Y., Itano, Y., Kosaka, F.: Metallothionein and zinc metabolism in endotoxin shock rats. Metallothionein-II. (ed. Kagi, J.H.R., Kojima, Y.), Birkhauser Verlag, Basel, 1987, p587-594.

6) Lehman-McKeeman, L.D., Andrews, G.K., Klaassen, C.D.: Mechanism of regulation of rat hepatic metallothionein-I and metallothioneinII levels following administration of zinc. Toxicol. Appl. Pharmacol. 92: 1-9, 1988.

7) Winge, D.R., Miklossy, K.A.: Differences in the polymorphic forms of metallothionein. Arch. Biochem. Biophys. 214: 80-88, 1982.

8) Lehman-McKeeman, L.D., Andrews, G.K., Klaassen, C.D.: Induction of hepatic metallothioneins determined at isoprotein and messenger RNA levels in glucocorticoid-treated rats. Biochem. J. 249: 429-433, 1988.

9) Cain, K., Griffiths, B.L.: A comparison of isometallothionein synthesis in rat liver after partial hepatectomy and parental zinc injection. Biochem. J. 217: 85-92, 1984.

10) Karin, M., Imbra, R.J., Heguy, A., Wong, G.: Interleukin 1 regulates human metallothionein gene expression. Mol. Cell Biol. 5: 2866-2869, 1985. 